\title{
PELAKSANAAN PEMERIKSAAN LAPORAN KEUANGAN PEMERINTAH DAERAH OLEH ANGGOTA TIM YUNIOR PADA BADAN PEMERIKSA KEUANGAN REPUBLIK INDONESIA PERWAKILAN PROVINSI SULAWESI UTARA
}

\author{
Rizal Y. Budiman \\ Jullie J. Sondakh \\ Winston Pontoh
}

\author{
Fakultas Ekonomi dan Bisnis Magister Akuntansi \\ Universitas Sam Ratulangi Manado \\ Email: rizal.budiman@bpk.go.id
}

\begin{abstract}
This study used a qualitative ethnographic method aimed to analyze the condition of the local government's financial statements examination by the examiner to the role of the Youth Team Member Audit Board and the things behind the condition. Data collected by means of interviews and observations at the time of examination of LKPD Talaud Islands and South Minahasa District for Fiscal Year 2013. The results showed that in the field of education and training of qualified inspectors have determined. In the examination of the planning process is not all examiners were involved in the preparation of the examination program while in the process of implementation of the inspection there are weaknesses such as inspection measures that can not be solved completely, different abilities to each examiner, and the preparation of paper checks that have not been fully resolved in the field. Furthermore, in the reporting process examiner had stints exceeding portion Youth Team Member.
\end{abstract}

Keywords: Examination, LKPD, Youth Team Member, Audit Board.

\section{Pendahuluan}

\subsection{Latar Belakang}

Laporan keuangan pemerintah daerah merupakan gambaran atas kondisi keuangan maupun tolok ukur informasi dari sebuah pemerintah daerah. Laporan keuangan tersebut dapat menjadi indikator mengenai sehat atau tidaknya kondisi keuangan suatu pemerintah daerah. Laporan keuangan adalah sebuah bentuk pertanggungjawaban pemerintah daerah kepada masyarakat atas pelaksanaan amanat pengelolaan keuangan daerah yang diberikan oleh masyarakat.

Semakin tingginya tuntutan masyarakat atas penyelenggaraan pemerintahan yang akuntabel dan transparan harus disikapi secara serius, dimana laporan keuangan pemerintah daerah termasuk dalam salah satu obyek akuntabilitas dan transparansi yang dituntut oleh masyarakat. Segenap jajaran pemerintah daerah harus memiliki komitmen agar good government dan clean government dapat tercapai. Untuk mengawal tercapainya good government dan clean government, maka perlu dilakukan pemeriksaan keuangan negara meliputi pemeriksaan atas pengelolaan keuangan negara dan pemeriksaan atas tanggung jawab keuangan negara. Berdasarkan Undang-Undang Nomor 15 Tahun 2004, BPK melaksanakan pemeriksaan atas pengelolaan dan tanggung jawab keuangan negara.

Diantara ketiga jenis pemeriksaan yang dapat dilakukan BPK, pemeriksaan laporan keuangan merupakan pemeriksaan yang bersifat mandatory, sehingga harus dilaksanakan secara rutin setiap tahunnya di setiap pemerintah daerah. Karena sifatnya yang menelurkan opini, maka pemeriksaan atas LKPD mendapatkan perhatian yang lebih besar dari pihak pemerintah daerah, kalangan media maupun masyarakat daripada jenis pemeriksaan lainnya. Bagi pemerintah daerah, opini yang diterbitkan BPK merupakan rapor atas kinerja yang mereka lakukan selama satu tahun anggaran. Oleh karena hal tersebut, maka pemeriksaan atas LKPD yang dipilih sebagai obyek pemeriksaan ini, bukan pemeriksaan Kinerja maupun PDTT. 
Karena beratnya beban BPK dalam melakukan melaksanakan pemeriksaan atas pengelolaan dan tanggung jawab keuangan negara, maka diperlukan pemeriksa yang memiliki kapabilitas mumpuni. Untuk menjadikan pemeriksa memiliki kapabilitas yang mumpuni, maka diterbitkanlah Peraturan BPK Nomor 1 Tahun 2007 tentang Standar Pemeriksaan Keuangan Negara (SPKN). Standar Pemeriksaan Keuangan Negara adalah patokan untuk melakukan pemeriksaan pengelolaan dan tanggung jawab keuangan negara dan dinyatakan dalam bentuk Pernyataan Standar Pemeriksaan (PSP). Anggota Tim Yunior, sebagai pemeriksa di level beginner tentunya memiliki tantangan tersendiri karena harus memenuhi standar umum tersebut sedangkan dari sisi pengalaman \& skill pemeriksaan yang dimiliki masih belum sebaik pemeriksa yang memiliki peran diatasnya. Oleh karena itu, Anggota Tim Yunior dipilih menjadi obyek pemeriksaan ini karena memiliki tantangan tersendiri dalam hal pengalaman dan skill pemeriksaan.

Fenomena tersebut mendorong penulis untuk melakukan penelitian dengan judul : "Pelaksanaan Pemeriksaan Laporan Keuangan Pemerintah Daerah oleh Anggota Tim Yunior pada Badan Pemeriksa Keuangan Republik Indonesia Perwakilan Provinsi Sulawesi Utara".

\subsection{Perumusan Masalah}

Berdasarkan latar belakang yang telah diuraikan di atas, maka menarik untuk dikaji mengenai bagaimana pelaksanaan pemeriksaan laporan keuangan pemerintah daerah oleh pemeriksa dengan peran Anggota Tim Yunior. Kajian ini juga mencakup hal-hal yang melatarbelakangi timbulnya kondisi tersebut yaitu kemahiran profesional, independensi, dan skeptisme profesional.

\subsection{Tujuan Penelitian}

Tujuan dari penelitian ini adalah menganalisa pelaksanaan pemeriksaan laporan keuangan pemerintah daerah oleh pemeriksa dengan peran Anggota Tim Yunior serta hal-hal yang melatarbelakangi kondisi tersebut yaitu kemahiran profesional, independensi, dan skeptisme profesional.

\subsection{Manfaat Penelitian}

1. Sebagai bahan masukan bagi pihak-pihak yang membutuhkan khususnya bagi BPK RI Perwakilan Provinsi Sulawesi Utara.

2. Bagi Magister Akuntansi Universitas Sam Ratulangi, penelitian ini diharapkan dapat memberikan bahan tambahan referensi untuk digunakan dalam penelitian selanjutnya.

\section{Tinjauan Pustaka}

\subsubsection{Audit}

Peraturan Menteri Pendayagunaan Aparatur Negara dan Reformasi Birokrasi Nomor 17 Tahun 2010 mendefinisikan pemeriksaan sebagai proses identifikasi masalah, analisis, dan evaluasi yang dilakukan secara independen, obyektif, dan profesional berdasarkan standar pemeriksaan, untuk menilai kebenaran, kecermatan, kredibilitas, dan keandalan informasi mengenai pengelolaan dan tanggung jawab keuangan negara.

Dalam Undang-Undang Nomor 15 Tahun 2004 disebutkan bahwa BPK melakukan pemeriksaan atas pengelolaan dan tanggung jawab keuangan negara yang terdiri atas pemeriksaan keuangan, pemeriksaan kinerja, dan pemeriksaan dengan tujuan tertentu. Pemeriksaan keuangan adalah pemeriksaan atas laporan keuangan. Pemeriksaan tersebut dilaksanakan berdasarkan standar pemeriksaan.

Dalam Keputusan Sekretaris Jenderal BPK RI Nomor 292/K/X-XIII.2/6/2011 tentang Petunjuk Teknis Jabatan Fungsional Pemeriksa, tugas dari Anggota Tim Yunior (ATY) dalam pemeriksaan adalah sebagai berikut :

1. Perencanaan

a. $\quad$ Melaksanakan administrasi penyusunan Program Pemeriksaan (P2).

b. Menyusun Program Kerja Perorangan (PKP) untuk pelaksanaan tugas-tugas dengan kompleksitas rendah dalam pemeriksaan pendahuluan. 

c. Melaksanakan tugas-tugas dengan kompleksitas rendah dalam pemeriksaan pendahuluan.
d. Menyusun Kertas Kerja Pemeriksaan (KKP) untuk pelaksanaan tugas-tugas dengan kompleksitas rendah dalam pemeriksaan pendahuluan.
e. Melakukan reviu atas Laporan Hasil Pemeriksaan (LHP) terdahulu.

2. Pelaksanaan.

Melaksanakan tugas-tugas dengan kompleksitas rendah dalam pelaksanaan pemeriksaan. Tugastugas yang dilaksanakan tersebut pada setiap penugasan dapat berbeda karena tergantung dari Program Pemeriksaan dan Program Kerja Perorangan yang dibuat oleh Tim berdasarkan tujuan pemeriksaan. Hal-hal yang umumnya dilaksanakan dalam pemeriksaan LKPD antara lain yaitu wawancara, reviu dokumen, dan pengamatan fisik, dimana dijelaskan lebih rinci pada Bab V mengenai Pelaksanaan Pemeriksaan.

3. Pelaporan
a. $\quad$ Menyiapkan bahan penyusunan Ikhtisar Hasil Pemeriksaan Semester (IHPS).
b. $\quad$ Melaksanakan administrasi dalam penyusunan LHP.
c. Menyiapkan bahan dan data untuk penyusunan LHP dalam pemeriksaan dengan kompleksitas rendah.

\subsubsection{Pemeriksa}

Salah satu teori yang terkait dengan good governance adalah stewardship theory (Shaw dalam Anwar; 2013). Stewardship theory dibangun di atas asumsi filosofis mengenai sifat manusia yakni bahwa manusia pada hakekatnya dapat dipercaya, mampu bertindak dengan penuh tanggung jawab, memiliki integritas dan kejujuran terhadap pihak lain. Implikasi teori stewardship theory dalam penelitian ini yaitu steward (dalam hal ini adalah pemeriksa) akan bekerja sebaik-baiknya untuk kepentingan principal (masyarakat dan organisasi pemeriksa).

Menurut Peraturan Menteri Pendayagunaan Aparatur Negara dan Reformasi Birokrasi Nomor 17 Tahun Tahun 2010 tentang Jabatan Fungsional Pemeriksa dan Angka Kreditnya, Jabatan Fungsional Pemeriksa (JFP) merupakan jabatan karier yang hanya dapat diduduki oleh seseorang yang telah berstatus Pegawai Negeri Sipil (PNS). Jabatan Fungsional Pemeriksa berkedudukan sebagai pelaksana teknis di bidang pemeriksaan di lingkungan BPK. Dalam Peraturan Badan Pemeriksa Keuangan Republik Indonesia Nomor 4 Tahun 2010 tentang Jabatan Fungsional Pemeriksa pada Badan Pemeriksa Keuangan, diterangkan bahwa Anggota Tim Yunior adalah peran yang dimiliki pemeriksa dengan tanggung jawab melaksanakan pemeriksaan dengan kompleksitas rendah dan disandang oleh Pemeriksa Pertama.

Menurut Kamus Besar Bahasa Indonesia, keahlian adalah kemahiran dalam suatu ilmu (pekerjaan). Keahlian atau kompetensi auditor adalah kemahiran yang dimiliki auditor yang ditunjukkan melalui pengalaman melakukan audit. Ida Suraida dalam Hudiwinarsih (2010:254) menyatakan bahwa "competence is professional expertise possessed by the auditors as a result of formal education, professional examinations and participation in training, seminars, symposium. Experience is related to audits of financial statements in terms of duration and number of assignments handheld". Berdasarkan hal tersebut dapat disimpulkan bahwa keahlian auditor adalah pengetahuan dan pengalaman memadai dalam bidang audit yang dimiliki oleh seorang auditor.

Dalam Peraturan BPK nomor 1 tahun 2007 tentang Standar Pemeriksaan Keuangan Negara, pemeriksa harus mematuhi standar umum yang salah satunya berkaitan dengan persyaratan kemampuan/keahlian pemeriksa. Persyaratan keahlian pemeriksa berkaitan dengan hal-hal berikut :

1. Pendidikan berkelanjutan.

2. Persyaratan kemampuan/keahlian pemeriksa.

Wikipedia mengartikan independen dengan bebas, merdeka, atau berdiri sendiri. Gill dalam Rusmin (2010:04) menyatakan "independence has two faces: independence in fact and independence in appearance. Both independence in fact anda independence in appearance are complementary, they 
cannot be completely separated from each other". Probabilitas auditor untuk melaporkan penyelewengan yang terjadi dalam sistem akuntansi klien bergantung pada independensi auditor (Pamudji, 2009:151).

Wilopo, Nurmala, dan Supriyati dalam Hudiwinarsih (2010:255) menyatakan "factors affecting the independence auditors such as family relationship with the client, financial ties and business relationship with clients, interfirm competition, provision of services othe than audit, long audits, major accountant's office, the amount of audit fee, anda giving or receiving the service".

Menurut Peraturan BPK nomor 1 tahun 2007 tentang Standar Pemeriksaan Keuangan Negara, pemeriksa harus mematuhi standar umum yang salah satunya adalah independensi. Menurut Pernyataan Nomor 01 tentang Standar Umum, dalam semua hal yang berkaitan dengan pekerjaan pemeriksaan, organisasi pemeriksa dan pemeriksa, harus bebas dalam sikap mental dan penampilan dari gangguan pribadi, ekstern, dan organisasi yang dapat mempengaruhi independensinya. Pemeriksa harus menghindar dari situasi yang menyebabkan pihak ketiga yang mengetahui fakta dan keadaan yang relevan menyimpulkan bahwa pemeriksa tidak dapat mempertahankan independensinya sehingga tidak mampu memberikan penilaian yang obyektif dan tidak memihak terhadap semua hal yang terkait dalam pelaksanaan dan pelaporan hasil pemeriksaan.

Menurut Bawono dan Singgih (2010:06), due professional care memiliki arti kemahiran profesional yang cermat dan seksama. Due profesional care menyangkut dua aspek, yaitu skeptisme profesional dan keyakinan yang memadai. Dalam Peraturan BPK nomor 1 tahun 2007 tentang Standar Pemeriksaan Keuangan Negara, pemeriksa harus mematuhi standar umum yang salah satunya berkaitan dengan persyaratan kemahiran profesional. Kemahiran profesional menuntut pemeriksa untuk melaksanakan skeptisme profesional, yaitu sikap yang mencakup pikiran yang selalu mempertanyakan dan melakukan evaluasi secara kritis terhadap bukti pemeriksaan. Pemeriksa menggunakan pengetahuan, keahlian, dan pengalaman yang dituntut oleh profesinya untuk melaksanakan pengumpulan bukti dan evaluasi obyektif mengenai kecukupan, kompetensi, dan relevansi bukti. Menerapkan kemahiran profesional secara cermat dan seksama memungkinkan pemeriksa untuk mendapatkan keyakinan yang memadai bahwa salah saji material atau ketidakakuratan yang signifikan dalam data akan terdeteksi. Keyakinan mutlak tidak dapat dicapai karena sifat bukti dan karakteristik penyimpangan.

\subsection{Penelitian Terdahulu}

Sebagai acuan dari penelitian ini dapat disebutkan beberapa hasil penelitian yang dilakukan antara lain yaitu :

Dalam penelitian Alim (2007) yang berjudul pengaruh kompetensi dan independensi terhadap kualitas auditor dengan etika auditor sebagai variabel moderasi membuktikan bahwa kompetensi berpengaruh signifikan terhadap kualitas auditor. Di lain sisi, interaksi kompetensi dan etika auditor tidak berpengaruh signifikan terhadap kualitas auditor. Penelitian ini juga menemukan bukti empiris bahwa independensi berpengaruh signifikan terhadap kualitas auditor.

Selanjutnya dalam penelitian Huntoyungo (2009) pada Inspektorat Provinsi Gorontalo tentang faktor-faktor yang berpengaruh pada kualitas audit dimana hasil penelitiannya menggambarkan bahwa keahlian dan independensi berpengaruh positif dan signifikan terhadap kualitas audit, sedangkan kecermatan dan keseksamaan tidak memiliki pengaruh signifikan.

Kisnawati (2012) dalam penelitiannya yang berjudul pengaruh kompetensi, independensi, dan etika terhadap kualitas audit pada auditor pemeritah di Inspektorat Kabupaten dan Kota se-Pulau Lombok menunjukkan bahwa secara simultan kompetensi, independensi, dan etika auditor berpengaruh terhadap kualitas audit serta secara parsial kompetensi dan independensi tidak berpengaruh terhadap kualitas audit, hanya etika auditor yang berpengaruh terhadap kualitas audit.

\section{Kerangka Konseptual}

\subsection{Kerangka Konseptual Penelitian}


Kerangka konseptual dirumuskan sebagai berikut:

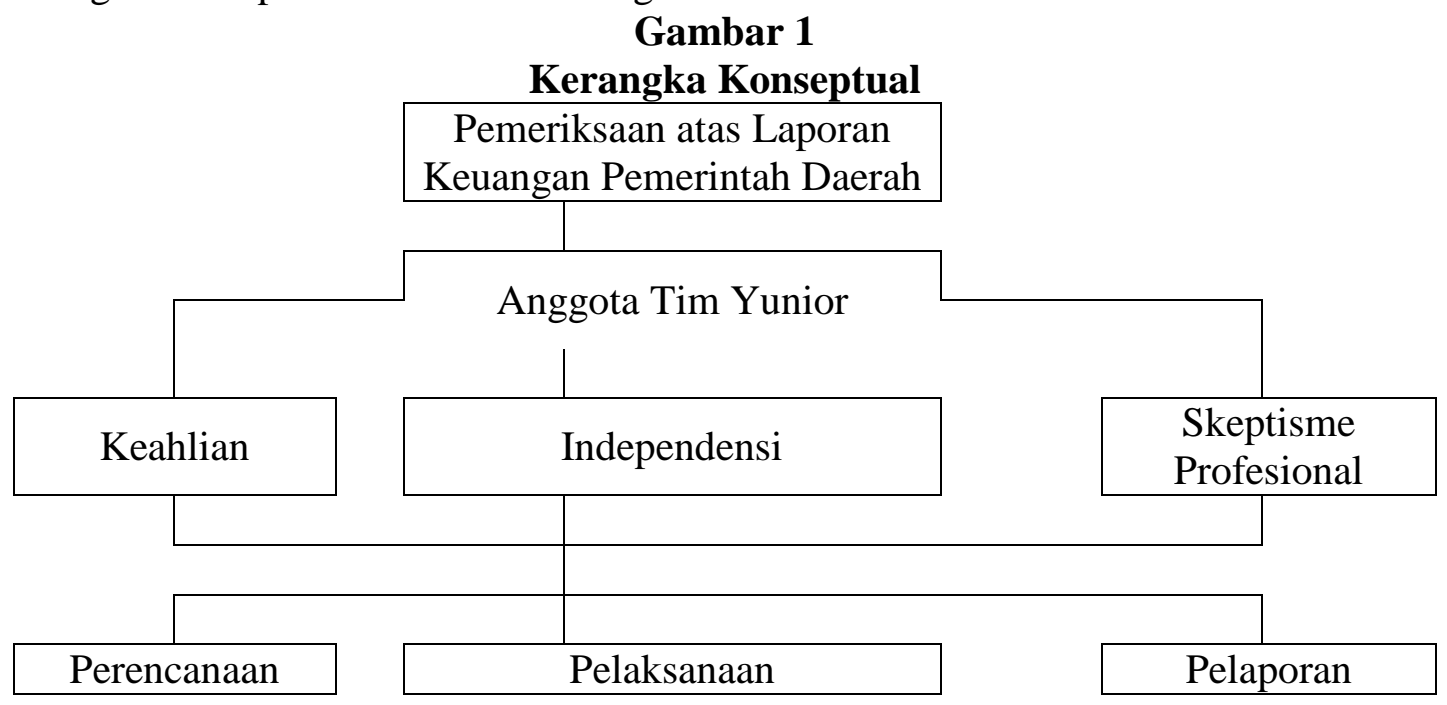

Sumber : Data Olahan (2014).

\subsection{Model Analisis}

Metode yang diterapkan dalam penelitian ini yaitu kualitatif secara etnografi. Sofian (2013:25) menyebutkan bahwa etnografi adalah sebuah proses dan hasil dari sebuah penelitian. Dengan teknik "observatory participant", etnografi menjadi sebuah metode penelitian yang unik karena mengharuskan partisipasi peneliti secara langsung dalam sebuah masyarakat atau komunitas sosial tertentu.

\section{Metode Penelitian}

\subsection{Jenis Penelitian}

Penelitian ini menggunakan metode kualitatif. Menurut Septiawan (2010:5), pendekatan kualitatif terutama layak untuk menelaah sikap atau perilaku dalam lingkungan yang agak artifisial, seperti dalam survei atau eksperimen. Kualitatif merupakan kajian berbagai studi dan kumpulan berbagai jenis materi empiris seperti studi kasus, pengalaman personal, pengakuan introspektif, kisah hidup, wawancara, dan pengamatan.

Metode kualitatif yang diterapkan untuk menilai pelaksanaan fungsi pemeriksaan laporan keuangan pemerintah daerah oleh pemeriksa dengan peran Anggota Tim Yunior (ATY) menggunakan teknik etnografi. Spradley (2007:4) menyebutkan bahwa tujuan penelitian etnografi adalah sebagai berikut :

1. Memahami rumpun manusia.

2. Melayani manusia.

Dalam kaitan dengan penelitian ini, peneliti adalah salah satu pemeriksa dengan peran ATY pada BPK RI Perwakilan Provinsi Sulawesi Utara sehingga berhubungan secara langsung dengan pemeriksa dengan peran ATY lainnya sehingga bisa meneliti bagaimana unsur keahlian, independensi, dan skeptisme profesional berperan dalam melaksanakan pemeriksaan. Peneliti juga melakukan participant observation, dimana peneliti melakukan pengamatan terhadap kegiatan sehari-hari dari obyek kelompoknya, melakukan pengamatan dan mewawancarai anggota kelompok yang terlibat di dalamnya.

\subsection{Responden Penelitian}

Dalam rangka memperoleh sejumlah informasi dan data yang berkaitan dengan penelitian ini, maka dibutuhkan dua responden yaitu dua responden pemeriksa ATY berlatar belakang ilmu akuntansi 
(dalam penelitian ini akan disebut sebagai A1 dan A2) dan dua responden pemeriksa ATY berlatar belakang ilmu non-akuntansi (dalam penelitian ini akan disebut sebagai N1 dan N2).

Pemilihan responden sebanyak 4 orang tersebut karena pemeriksaan LKPD atas sebuah pemerintah daerah hanya dilakukan satu kali dalam satu tahun oleh satu tim yang beranggotakan 4 orang yang berisi satu Ketua Tim dan tiga Anggota Tim. Pada tahun 2014 peneliti mendapatkan penugasan pemeriksaan atas LKPD sebanyak dua kali, pada Kabupaten Kepulauan Talaud dan Kabupaten Minahasa Selatan, dimana pada masing-masing tim tersebut terdapat satu ATY dengan latar belakang akuntansi dan satu ATY berlatar belakang non akuntansi sehingga peneliti bisa mendapatkan responden sebanyak empat orang sebagaimana tersebut diatas. Jumlah respoden tersebut merupakan jumlah maksimal yang bisa didapatkan dalam tim pemeriksa mengingat komposisi tim yang ada.

\subsection{Instrumen Penelitian}

Penelitian etnografi menggunakan tiga cara pengumpulan data yaitu wawancara, observasi, dan dokumen (Emzir dalam Sofian, 2013:31). Etnografer mengeksplorasi key informant, yaitu individu yang dapat memberikan pandangan dan informasi yang berguna tentang kelompok dan dapat mengarahkan peneliti dalam mengumpulkan data dan informasi, yang dalam penelitian ini informasi berusaha dikumpulkan dari pemeriksa dengan peran ATY dengan latar belakang akuntansi dan nonakuntansi.

\subsection{Obyek dan Waktu Penelitian}

Penelitian berlokasi di Provinsi Sulawesi Utara dan yang menjadi unit analisis adalah Badan Pemeriksa Keuangan (BPK) RI Perwakilan Provinsi Sulawesi Utara. Penelitian berlangsung selama 6 (enam) bulan.

\subsection{Teknik Pengumpulan dan Analisis Data}

Teknik pengumpulan data yang akan digunakan dalam melaksanakan penelitian ini adalah :

1. Wawancara

2. Observasi

\section{Analisis dan Pembahasan Hasil Penelitian \\ 5.3.1. Standar Umum Pemeriksa}

Berdasarkan hasil penelitian, diketahui bahwa BPK telah membuat sistem yang cukup memadai untuk mengakomodir para pemeriksa agar memiliki kemampuan yang mumpuni. Dalam bidang pendidikan formal, seluruh responden telah memenuhi kualifikasi yaitu berlatar belakang pendidikan Strata Satu. Dalam hal pendidikan dan pelatihan, sebelum diangkat sebagai pemeriksa, pegawai BPK harus melalui proses sertifikasi pemeriksa. Seluruh responden telah lulus dan mendapatkan sertifikasi sebagai pemeriksa yaitu pada tahun 2009 dan 2011 sehingga telah memenuhi syarat untuk diangkat sebagai pemeriksa. Setelah diangkat sebagai pemeriksa, maka BPK memberikan kesempatan yang seluas-luasnya bagi pemeriksa untuk mengembangkan diri dengan menyelenggarakan diklat secara rutin setiap bulannya di Pusdiklat dan 3 Balai Diklat. Selanjutnya, dalam hal independensi, selama menjadi pemeriksa seluruh responden tidak pernah mengalami gangguan independensi dalam pelaksanaan pemeriksaan karena seluruh responden tidak memiliki keterkaitan dengan entitas maupun hubungan kekerabatan di Provinsi Sulawesi Utara. Dalam penerapan skeptisme profesional, hanya responden A1, A2, dan N1 yang menggunakannya dalam pelaksanaan pemeriksaan, sedangkan responden N2 belum menerapkan skeptisme profesional dalam pelaksanaan pemeriksaan.

\subsubsection{Perencanaan Pemeriksaan}

Dalam melaksanakan administrasi dalam penyusunan P2-Pendahuluan, responden A1 melakukan pengumpulan informasi dari media dan LHP sebelumnya mengenai permasalahan yang ada 
pada auditee serta mengumpulkan data dari lama e-audit diantaranya dana transfer dari pemerintah pusat dan realisasi belanja, sedangkan responden A2 menyiapkan peraturan-peraturan yang berkaitan dengan pemeriksaan. Responden $\mathrm{N} 1$ dan $\mathrm{N} 2$ tidak terlibat dalam proses administrasi dalam penyusunan P2-Pendahuluan. Dalam penyusunan Program Kerja Perorangan (PKP) semua responden membuat dan mendokumentasikannya. PKP tersebut dibuat berdasarkan langkah-langkah pada P2Pendahuluan dan pembagian tugas yang diberikan oleh Ketua Tim.

Dalam pelaksanaan pemeriksaan pendahuluan, Responden A1,A2, N1, dan N2 melaksanakan pekerjaannya sesuai sasaran pemeriksaan yang telah diterjemahkan dalam langkah-langkah yang telah ditentukan dalam PKP, yaitu untuk mengidentifikasi dan memperoleh gambaran umum tentang proses bisnis di lingkungan pemerintah daerah dengan memahami bagaimana lingkup kerja entitas diatur, dikelola, dan dikendalikan. Pada saat melakukan pemeriksaan pendahuluan, responden A1, A2, N1, dan N2 juga membuat kertas kerja pemeriksaan (KKP) atas pemeriksaan pendahuluan. Selain itu, juga dilakukan reviu atas LHP terdahulu untuk melihat apakah permasalahan-permasalahan yang timbul pada tahun sebelumnya telah diselesaikan dan tidak muncul lagi di tahun berjalan. Dari proses perencanaan tersebut, diketahui bahwa belum seluruh responden terlibat dalam proses penyusunan P2, dimana seharusnya seluruh anggota tim berperan dalam proses tersebut. Anggota tim harus berperan dalam tiap tahapan perencanaan yang telah ditentukan agar memahami dengan baik program pemeriksaan yang akan dijalankan pada saat pelaksanaan pemeriksaan.

\subsubsection{Pelaksanaan Pemeriksaan}

Dalam proses pelaksanaan pemeriksaan baik responden A1, A2, N1, maupun N2 tidak selalu dapat menyelesaikan seluruh langkah pemeriksaan karena keterbatasan waktu. Dalam pelaksanaan pemeriksaan terinci tersebut, responden $\mathrm{A} 1, \mathrm{~A} 2, \mathrm{~N} 1$, dan $\mathrm{N} 2$ memiliki perbedaan kemampuan dalam menangani akun-akun yang ditugaskan Ketua Tim karena faktor pengalaman maupun latar belakang pendidikan. Pada saat pelaksanaan pemeriksaan terinci, pemeriksa juga diharuskan membuat Kertas Kerja Pemeriksaan (KKP) sebagai dokumentasi hasil pemeriksaan. Responden A1, A2, N1, dan N2 pada saat pemeriksaan lapangan memang telah membuat KKP namun belum sempurna. Proses penyempurnaan KKP baru dilaksanakan setelah selesainya pemeriksaan lapangan. Hal tersebut terjadi karena terbatasnya waktu pemeriksaan sehingga lebih berkonsentrasi pada menjalankan langkahlangkah pemeriksaan.

Pelaksanaan pemeriksaan LKPD tidak dapat dilepaskan dari ilmu akuntansi karena sangat berkaitan erat dengan laporan keuangan. Responden A1 merasa bahwa latar belakangnya di bidang akuntansi sangat membantu dalam melakukan pemeriksaan, begitu pula dengan responden A2. Sementara itu responden N1 dan N2 meskipun berlatar belakang non-akuntansi namun tidak mengalami masalah yang berarti dengan proses pemeriksaan karena dalam pembagian penugasan tidak pernah mendapatkan akun yang sangat berkaitan erat dengan ilmu akuntansi seperti misalnya kas daerah maupun memperoleh penugasan untuk melakukan penyusunan laporan keuangan.Dalam pemeriksaan LKPD di kabupaten/kota, komposisi tim terdiri atas 1 KT dan 3 AT dengan jangka waktu pemeriksaan pendahuluan selama 30 hari dan pemeriksaan terinci selama 40 hari. Responden A1, A2, dan N1 merasakan bahwa hal tersebut masih kurang karena tiap entitas memiliki masalah dan kompleksitas yang berbeda, sedangkan responden N2 menyatakan bahwa komposisi tim dan jangka waktu pemeriksaan telah mencukupi.

Dari proses pelaksanaan tersebut, diketahui bahwa masih terdapat kelemahan-kelemahan dalam pelaksanaan pemeriksaan, yaitu yang pertama adalah komposisi tim dan jangka waktu pemeriksaan yang belum disesuaikan dengan besarnya anggaran dan kompleksitas permasalahan yang berbeda di tiap entitas. Kedua, langkah pemeriksaan belum seluruhnya dapat diselesaikan pada saat pelaksanaan pemeriksaan sehingga membebani pemeriksa untuk mengerjakannya padaa saat pelaksanaan pemeriksaan telah berakhir. Ketiga, penyusunan kertas kerja pemeriksaan belum dapat diselesaikan pada saat pelaksanaan pemeriksaan sehingga membebani pemeriksa untuk mengerjakannya padaa saat pelaksanaan pemeriksaan telah berakhir. Terakhir, meskipun sama-sama menyandang peran ATY namun diantara responden memiliki kemampuan yang berbeda dan terspesialisasi pada akun-akun 
tertentu. Hal tersebut harus direduksi agar tiap ATY memiliki kemampuan yang merata pada tiap akun karena nantinya setiap ATY akan menjadi ketua tim pemeriksaan sehingga harus memiliki kemampuan yang lengkap dan memadai.

\subsubsection{Pelaporan Pemeriksaan}

Meskipun tugas Anggota Tim seharusnya hanya menyiapkan bahan dan data serta administrasi, namun pada prakteknya responden A1, A2, dan N1 telah melaksanakan tugas yang seharusnya dilaksanakan oleh Ketua Tim, sementara responden N2 tidak terlibat dalam proses penyusunan laporan. Dalam proses pelaporan, responden A1 melakukan koreksi Konsep Hasil Pemeriksaan (KHP) yang telah dikoreksi oleh Pengendali Teknis (PT) dan Penanggung Jawab (PJ) serta melakukan pengujian ketepatan perhitungan. Responden A2 melakukan editing redaksional jika ada koreksi KHP. Sama dengan responden A1, responden N1 melakukan koreksi Konsep Hasil Pemeriksaan (KHP) yang telah dikoreksi oleh Pengendali Teknis (PT) dan Penanggung Jawab (PJ) serta melakukan pengujian ketepatan perhitungan. Dari proses pelaporan tersebut, diketahui bahwa belum seluruh responden terlibat dalam proses penyusunan LHP, dimana seharusnya seluruh anggota tim berperan dalam proses tersebut. Anggota tim harus berperan dalam tiap tahapan pelaporan yang telah ditentukan agar memahami dengan baik proses penyusunan LHP.

Mengingat begitu vital peran yang diemban BPK dalam melakukan pemeriksaan atas pengelolaan keuangan negara/daerah, maka profesionalisme pemeriksa dalam menjalankan tugas menjadi satu hal yang penting. Berkaitan dengan stewardship theory, dimana steward (dalam hal ini adalah pemeriksa) akan bekerja sebaik-baiknya untuk kepentingan principal (masyarakat dan organisasi pemeriksa), Sementara itu, meskipun telah memiliki sistem yang cukup baik, namun masih terdapat kelemahan diantaranya dalam menentukan komposisi tim dan jangka waktu pemeriksaan dimana belum sepenuhnya mempertimbangkan resiko pemeriksaan dan besarnya anggaran yang diperiksa.

\section{Simpulan dan Saran \\ 6.1. Simpulan}

Berdasarkan hasil penelitian yang telah dilakukan, maka peneliti menyimpulkan hal-hal sebagai berikut :

a. Dalam hal standar umum pemeriksa, responden telah memenuhi kualifikasi sebagai pemeriksa BPK karena berlatar belakang pendidikan Strata Satu (S1), telah memiliki sertifikasi pemeriksa sehingga memiliki dasar untuk melaksanakan pemeriksaan dan BPK telah mengakomodir kebutuhan pendidikan dan pelatihan (diklat) pegawainya dengan cukup baik sehingga setiap responden dapat memenuhi standar minimal jam diklat yang disyaratkan, bahkan melebihi standar tersebut. Faktor independensi belum dapat teruji sepenuhnya karena sebelum menjadi pegawai BPK para responden tidak memiliki keterkaitan dengan Provinsi Sulawesi Utara. Dalam hal penggunaan skeptisme profesional, belum seluruh responden menggunakan skeptisme profesionalnya dalam melaksanakan pemeriksaan.

b. Dalam proses perencanaan pemeriksaan peran serta Anggota Tim belum merata dimana masih ada responden yang belum terlibat dalam proses perencanaan pemeriksaan.

c. Dalam proses pelaksanaan pemeriksaan masih terdapat kelemahan-kelemahan dalam pelaksanaan pemeriksaan, yaitu yang pertama adalah komposisi tim dan jangka waktu pemeriksaan yang belum disesuaikan dengan besarnya anggaran dan kompleksitas permasalahan yang berbeda di tiap entitas. Kedua, langkah pemeriksaan belum seluruhnya dapat diselesaikan pada saat pelaksanaan pemeriksaan sehingga membebani pemeriksa untuk mengerjakannya padaa saat pelaksanaan pemeriksaan telah berakhir. Ketiga, penyusunan kertas kerja pemeriksaan belum dapat diselesaikan pada saat pelaksanaan pemeriksaan sehingga membebani pemeriksa untuk mengerjakannya padaa saat pelaksanaan pemeriksaan telah berakhir. Terakhir, meskipun samasama menyandang peran ATY namun diantara responden memiliki kemampuan yang berbeda dan terspesialisasi pada akun-akun tertentu. 
d. Dalam proses pelaporan pemeriksaan peran serta Anggota Tim juga belum merata dimana masih ada responden yang belum terlibat dalam proses pelaporan pemeriksaan.

\subsection{Saran}

Berdasarkan simpulan tersebut, maka peneliti menyarankan untuk :

a. Menjaga kontinuitas pemeriksa dalam mengikuti diklat agar selalu memenuhi standar minimal yang disyaratkan.

b. Memberikan pembagian tugas secara merata pada ATY saat proses perencanaan, pelaksanaan, dan pelaporan pemeriksaan.

c. Dalam penyusunan langkah P2 harus mempertimbangkan waktu pelaksanaan agar seluruh langkah pemeriksaan berikut kertas kerja pemeriksaan dapat diselesaikan pada saat pelaksanaan pemeriksaan di lapangan.

d. Memberikan pelatihan dan pengalaman yang memadai kepada Anggota Tim agar dapat menguasai semua akun dengan sama baiknya, tidak hanya menguasai akun-akun tertentu.

e. Mempertimbangkan faktor resiko dan besarnya anggaran dalam menyusun komposisi tim dan menentukan jangka waktu pemeriksaan.

f. Menekankan penggunaan skeptisme profesional dalam melaksanakan pemeriksaan.

\section{Daftar Pustaka}

Alim,M. Nizarul, 2007, Pengaruh Kompetensi dan Independensi Terhadap Kualitas Auditor dengan Etika Auditor Sebagai Variabel Moderasi, Simposium Nasional Akuntansi X.

Anwar, Azwar, 2013, Peran SPI Terhadap Pencapaian Opini WTP dan Pencegahan Korupsi Melalui Penerapan GUG (Analisis Studi Pustaka), Ikhtiyar Volume 11.

Bawono, Icuk Rangga, dan Elisha Muliani Singgih, 2010, Faktor-Faktor Dalam Diri Auditor dan Kualitas Audit: Studi Pada KAP 'Big Four' di Indonesia, Simposium Nasional Akuntansi XIII.

Hudiwinarsih, Gunasti, 2010, Auditors Experience, Competency, and Their Independency as The Influential Factors in Professionalism, Journal of Economics, Business, and Accountancy Ventura Volume 13 No.3.

Huntoyungo, Siti Badriyah, 2009, Faktor-Faktor yang Berpengaruh Terhadap Kualitas Audit (Studi pada Inspektorat Gorontalo), Tesis.

Keputusan Sekretaris Jenderal BPK RI Nomor 292/K/X-XIII.2/6/2011, Petunjuk Teknis Jabatan Fungsional Pemeriksa, Jakarta.

Kisnawati, Baiq, 2012, Pengaruh Kompetensi, Independensi, dan Etika Terhadap Kualitas Auditor (Studi Empiris pada Auditor Pemerintah di Inspektorat Kabupaten dan Kota se-Pulau Lombok, Jurnal Bisnis dan Kewirausahaan Volume 8 Nomor 3.

Pamudji, Sugeng, 2009, Pengaruh Kualitas Audit dan Auditor Baru Serta Pengalaman Bagian Akuntansi Terhadap Kepuasan dan Loyalitas Klien, Jurnal Akuntansi dan Auditing Indonesia Volume 13 No.2.

Peraturan Badan Pemeriksa Keuangan Nomor 1 Tahun 2007, Standar Pemeriksaan Keuangan Negara, Jakarta.

Peraturan Menteri Pendayagunaan Aparatur Negara dan Reformasi Birokrasi Nomor 17 Tahun 2010, Jabatan Fungsional Pemeriksa dan Angka Kreditnya, Jakarta.

Rusmin, 2010, Auditor Quality and Discretionary Accruals: Case of Australian Listed Companies, Jurnal Akuntansi \& Auditing Indonesia Volume 14 No.1. 
Septiawan, Santana K., 2010, Metode Penelitian Kualitatif, Edisi Kedua, Yayasan Obor Indonesia, Yogyakarta.

Sofian, Siska, 2013, Persepsi Pengguna pada Penerapan Lelang Pengadaan Secara Elektronik (LPSE) Salah Satu Wujud Peningkatan Kualitas Good Governance di Kementerian Agama se-Sulawesi Utara, Tesis, Universitas Sam Ratulangi, Manado.

Spradley, James P., 2007, Metode Etnografi, Edisi Kedua, Tiara Wacana, Yogyakarta.

Undang-Undang Nomor 15 Tahun 2004, Pemeriksaan Pengelolaan dan Tanggung Jawab Keuangan Negara, Jakarta.

Undang-Undang Nomor 15 Tahun 2006, Badan Pemeriksa Keuangan, Jakarta.

Utami, Intiyas, dan Ertambang Nahartyo, 2013, Auditors Personality in Increasing The Burnout, Journal of Economics, Business, and Accountancy Ventura Volume 16 No.1.

www.bpk.go.id. 